\title{
INSTRUCTIONAL MEDIA AND MANAGEMENT OF ELEMENTARY SCHOOLS EDUCATION IN KWARA STATE NIGERIA
}

\author{
Abdullahi Nimota Jibola Kadir \\ Department of Educational Management, Faculty of Education, University of Ilorin, Nigeria \\ abdullahi.njk@unilorin.edu.ng
}

Citation: Kadir, A. N. J. (2020). Instructional media and management of elementary schools education in Kwara State Nigeria. Indonesian Journal of Elementary Teachers Education, 1 (1), 9-26

Received: 03-27-2020 Accepted: 05-29-2020 Published: 05-31-2020

\begin{abstract}
Instructional media within the educational institutions could bring the world into the classroom and enhance effective management of education. This study examined the relationship between projected media, non-projected visual, simulation and games and management of elementary education in public primary schools in Kwara State, Nigeria. Stratified random sampling technique was used to select 306 head teachers from a population of 1, 406 and 384 teachers from a population of 14,206 in public primary schools in Kwara State with the use of Research Advisor (2006) table of determining sample size of a known population. Data was collected using Instructional Media and Management of Elementary Education Questionnaire (IMMEEQ). The data was analysed using descriptive statistics and t-test statistical analysis. The results showed that there were significant and positive relationship between projected media, non-projected visual, simulation and games and management of elementary education. Based on the findings it was therefore recommended that government and head teachers should provide appropriate projected media for teachers to disseminate information to learners in the classroom. Also, head teachers should continue to encourage teachers to make use of non-projected visual to arouse the interest and gain the attentions of the learners in order to aid the teachers explanations and make learning of subject matter understandable to learners during teaching and learning process. Furthermore, teachers should also make use of simulation and games to enhance effective learners performance in learning in order to realize effective management of elementary schools education in Nigeria.
\end{abstract}

Keywords: instructional media; motivation; projected media; elementary education; organising. 


\section{INTRODUCTION}

Instructional media is an integral part of the school in which education system can improve. Every job has its own tools, teaching has got its own resources, which anyone who has chosen teaching as a career must be aware of. In this age of technology that learners need to understand many things relating to education, words alone are not enough. Teaching becomes more interesting when concrete objects are used rather than oratory words from the teacher which are easily forgotten. The development of instructional media however sets the pace for a literary-based approach of teaching which emphasizes the promotion of knowledge and change of abstract to concrete learning. Instructional media enhance and facilitates learning which leads to fostering and stimulations of learning environment.

Elementary education refers to children's first formal education or schooling before secondary schools such as early childhood care education and primary education. It is a foundation step in preparing children for further learning in life. Elementary education is where most children learn educational basics of reading, writing, arithmetic and fundamental concepts of science. In Nigeria, elementary education refers to pre-primary education (early childhood care education) for age two to five years and primary education for children in age six to eleven years above according to National Policy on Education (2013). Primary education ranges from primary 1 to primary 5-6. It provides learners with fundamental skills that will serve as the basis needed for the rest of their academic careers (Igbokwe \& Igbokwe, 2010). For effective management of teaching and learning in primary education, the teachers has to make use of appropriate instructional media such as projected media (computer, television, videos, teaching machines), non-projected visual (flip charts, posters, still pictures, wall charts, textbooks) and simulation and games (puzzles, LEGO, mock ups, drama, plays, games).

Several studies have been conducted on instructional resources and effectiveness of education. Obwoge and Mosol (2016) carried out the utilization of instructional media in training health professional. Hilda and Bernard (2015) investigated the availability and use of instructional materials in teaching of conflict and conflict resolution in primary schools in Nandi North district, Kenya. Sample of 45 teachers was selected purposively. Questionnaire and classroom observation checklist were used for data collection. Descriptive statistics such as frequencies and percentages were used to analyze the data collected. The findings of the study show that teachers lacked sufficient instructional materials for effective teaching. Furthermore, Okpechi and Denwigwe (2017) embarked on the teacher and teaching with instructional materials in the teaching of science subjects and the contribution of guidance and counselors therein. Sample of 500 participants were selected from four higher institutions in Cross River State. Self-designed questionnaire titled "Preferred Crisis Management Strategies Questionnaire" was used to collect data. The data collected was analyze using independent t-test. The finding revealed that crisis management strategy by lecturers was significantly low in higher institutions in Cross River State. Awolaju (2016) investigated instructional materials as correlates of students' academic performance in Biology in senior secondary schools. Dhakal (2017) conducted a similar study on the availability and utilization of instructional materials in teaching geopraphy in secondary schools. Sample of 174 students were selected. The data collected were analyzed using percentages. The result shows that graphic and printed instructional media for teaching geography are available. There are numerous areas on instructional media and education that are yet to be covered by these scholars. These areas include instructional media and management of elementary education in Kwara State, Nigeria. Also, to the researcher' knowledge, there have been no research in Nigeria so far that looked at projected media, non-projected visual media and simulations and 
Indonesian Journal of Elementary Teachers Education (IJETE)

p-ISSN: 2615-2606 \& e-ISSN: 2615-7853

Volume 1, Number 1, May 2020

https://journal.uniku.ac.id/index.php/ijete

games as critical indices to measure instructional media towards effective management of elementary education. Hence, this study endeavour to fill the gaps left by the previous scholars. The following objectives have been formulated to guide the conduct of the present study: (1) Determine the relationship between projected media and management of elementary education in Kwara State; (2) Investigate the relationship between non-projected visual media and management of elementary education in Kwara State, and (3) Examine the relationship between simulations and games and management of elementary education in Kwara State.

Instruction primarily deals with the development of knowledge and understanding in the learners. It can be seen as the system of leading the learners through body of knowledge that can enhance the learner's ability to comprehend (Oladosun, 2016). Media on the other hand, is the channel through which teacher communicate the concepts of lesson to learners in a more concrete manner rather than abstract approach (Obwoge \& Mosol, 2016). Instructional media are computer-based tools for learning used to clarify points towards allowing learners to interact with words, images and ideas so as to develop their abilities. In the same vein,Instructional media are materials used to facilitate teaching and learning process for the purpose of making the content of instructions more meaningful and better achievement of educational goals and objectives (Bright \& Abdulganiyu, 2015; Hilda \& Bernard, 2015; Dhakal, 2017). Instructional media are also information carrying technologies which a classroom teacher can use in concretizing instruction and enhancing teaching and learning process (Yusuf \& Ogunlade, 2016). Therefore, teaching and learning with instructional media help the teachers to manipulate real objects for different educational context in order to achieve meaningful and productive learning. There are different criteria that should be considered in selecting appropriate instructional media such as the age level of learners, safety of learners, cost implication of materials, intelligence of the learners, motivation, curriculum relevancy, skill and attitude of learners to mention but few. Instructional meadia are materials use in teaching and learning in order to make teaching more interesting, interactive and exciting to learners with the purpose of achieving instructional objectives (Onasanya, 2016). Instructional media in this study refers to the use of projected media, non- projected visual media and simulations and games for effective management of elementary education.

Projected media are those devices which are used in classroom to arouse learners' interest in learnings process, stimulate thinking and cognize as well as making teaching effective (Merchant et.al, 2014). When using projected visual as instructional media, it gives chance to instructors to make a more professional and consistent performance, making learning practice apple real, concretize the abstract information and supplement the work of the teacher while teaching. Projected media are those materials that appeals to the sense of seeing and hearing concurrently and give learners the opportunities to take the instruction in its original or real form (Onasanya, 2016).

Non-projected visual media are tools that make lesson clearer to understand. It is a pictorial material which appeal to the sense of sight and do not necessarily require electricity or battery for showing them. These include posters, flip charts, wall charts, still pictures, textbooks, bill boards, chalk boards, magazine and the likes.

Games are organized activities with stipulated rules for play in which two or more learners interact so as to achieve a clearly stated instructional objectives. Simulations and games are a game-based method that can be used to facilitate teaching and learning at any level of education (Olubola \& Francisca, 2013), simulations and games was seen as an 
exercise that bring about the required characteristics of making learning real with stated rules and regulations (Adobor \& Deneshfar, 2006; Pasin \& Giroux, 2011; Lewis \& Maylor, 2007).

Instructional media aid effective management of elementary education in that it improves communication between the teacher and the learners, it motivates learners to learn and maintain interest in learning as well as helps teacher to effectively organize and control the classroom in on orderly manner (Abdullahi \& Tijani, 2019). The concept of management is a widespread topic of concern and has been conceptualized in different perspectives. Management is the process concerned with planning, organizing, directing, controlling and budgeting (Abdullahi, Mafara \& Mayanchi, 2016). Management can also be viewed as the process through which resources are made available in educational institutions and maximum utilization of these resources to accomplish the stated goals and objectives of education (Okpechi \& Denwigwe, 2017). This implies that it is a process of making resources available and appropriate use of the set resources towards the attainment of desire educational goals.

The theoretical framework of this study is based on Fleming (2006) learning theory. Fleming suggested four modalities that are used for learning information called VARK. The acronym VARK stands for Visual (V), Auditory (A), Read/write (R) and Kinesthetic (K) sensory modalities. Visual modality includes information in maps, charts, graphs, flow charts, posters, still pictures, labelled diagrams and other devices that people use to represent what could have been presented in words. Auditory describes information that is heard or spoken such as group discussion, radio, television, mobile phones, web-chart and the likes. Read/write modality described information display as words such as using text-based input and output device and books. Kinesthetic refer to the perceptual information related to the use of experience and practice (simulated games or real). It includes videos and movies, games, simulations and other devices for practice and application.

This theory can be effective in the school system such that it helps teachers to make choice of which is the most suitable mode for teaching and learning process. Teachers can identify by whether learners have a preference for visual learning (pictures, diagrams, charts, posters), auditory learning (music, lectures, discussion), reading and writing (reading textbooks, taking notes), or kinesthetic learning (simulations, games, experiments, movement). The researcher anchored on this theory because it allows teacher aligning teaching methods to learning styles in order to enhance effective dissemination of information and impacting of appropriate knowledge. It also gives learners opportunities to expose to variety learning styles as well as provides a medium for self-knowledge, productive learning experience and exploring opportunities in the classrooms toward effective management of elementary education so as to realize stated educational goals and objectives.

\section{RESEARCH METHOD}

\section{Research Design}

The research design used in this study was qualitative research design. The design was considered appropriate because it support the researcher to examine the interaction that exist between instructional media and management of elementary education. It also assists by giving the research opportunity to obtain the view of the sample population, analyze the collected data using suitable data analysis technique and reach a rational conclusion about the population from the findings of the study (Drew, Hardman \& Hosp, 2008; Johnson \& Christensen, 2008). 


\section{Participant}

This study focused on public primary schools in Kwara State, Nigeria. There are 1,406 public primary schools and 14,216 teachers in the State. The target population of this study consisted of 1, 406 head teachers and 14,216 teachers in Kwara State as at the time of study. Sample of 306 head teachers and 384 teachers were selected using Research Advisor (2006) table of determining sample size of a know population.

Table 1. Population Sample

\begin{tabular}{cccccc}
\hline S/N & $\begin{array}{c}\text { Senatorial } \\
\text { Districts }\end{array}$ & $\begin{array}{c}\text { Total Number } \\
\text { of Head } \\
\text { Teachers }\end{array}$ & $\begin{array}{c}\text { Sample } \\
\text { Head } \\
\text { Teachers }\end{array}$ & $\begin{array}{c}\text { Total Number } \\
\text { of Teachers }\end{array}$ & $\begin{array}{c}\text { Sample of } \\
\text { Teachers } \\
\text { Selected }\end{array}$ \\
\hline $\mathbf{1}$ & Kwara Central & 385 & 84 & 3676 & 99 \\
$\mathbf{2}$ & Kwara North & 415 & 90 & 4877 & 132 \\
$\mathbf{3}$ & Kwara South & 606 & 132 & 5663 & 153 \\
& Total & 1,406 & 306 & 14,216 & 384 \\
\hline
\end{tabular}

Proportional sampling technique was used to select sample of 306 head teachers and 384 teachers across the three senatorial districts, this involves obtaining the population of head teachers and teachers in each selected primary school in the three senatorial districts in Kwara State and selecting the sample proportionally from these population as shown in table 1. Stratified random sampling technique was used to select head teachers and teachers from the sample schools so as to guarantee that all groups of head teachers and teachers were given equivalent chance of being selected.

\section{Data Collection}

The research instrument for this study was self-constructed questionnaire titled "Instructional Media and Management of Elementary Education Questionnaire" (IMMEEQ) and adapted questionnaire. A total number of 24 items were used to measure instructional media with three subscales: projected media ( 8 items), non-projected visual (6 items) and simulations and games (10 items). The items of questionnaire regarding management of elementary education was concluded from Abdullahi (2016) on motivation with (5 items), Ong, Dino, Calimag and Hidalgo (2019) on communication (7 items) and Abdullahi (2017) organizing (5 items). Participants responded to four-point Likert scale ( $4=$ strongly agree; $3=$ agree; 2 disagree; $1=$ strongly disagree). The criterion mean is given thus: $4+3+2+1 / 4=$ 2.50. The criterion mean portrays that any item that is above or equal to the criterion mean value of 2.50 is agreed while the one below the criterion mean value is disagreed by the respondent. (Bergkvist \& John, 2007; Dolnicar \& Grun, 2007; Allen \& Christopher, 2007) conclude that 4-point Likert scale answer format was completed quicker than 5 and 7-point scales.

To ensure the content validity of the instrument, draft copies of the instrument were given to three experts in measurement and evaluation and two experts in educational management. Relevant corrections and adjustment were made based on their recommendations and observations. In addition, 30 corrected copies were further administered to head teachers and teachers who are part of the sample to observe their understanding and clarity of the items of the wording and instructions of the questions and scales in order to discover if there is any difficulty that may arise in filling the questionnaire. Therefore, some suggestions made were corrected appropriately before sending administering the final copies. Cronbach's alpha was used to test the reliability of the instrument as shown 
in Table 2. The value for Cronbach's alpha for this study was proven to be acceptable and reliable.

Table 2. Reliability Test for IMMEEQ

\begin{tabular}{|c|c|c|c|c|}
\hline Variable & Sub-variable & $\mathbf{N}$ & $\begin{array}{c}\text { Cronbach's } \\
\text { Alpha }\end{array}$ & Decision \\
\hline \multirow[t]{3}{*}{$\begin{array}{l}\text { Instructional } \\
\text { Media }\end{array}$} & Projected media & 8 & 0.86 & $\begin{array}{c}\text { All items are acceptable } \\
\text { and reliable }\end{array}$ \\
\hline & $\begin{array}{l}\text { Non-projected } \\
\text { visual }\end{array}$ & 6 & 0.80 & $\begin{array}{c}\text { All items are acceptable } \\
\text { and reliable }\end{array}$ \\
\hline & $\begin{array}{l}\text { Simulations and } \\
\text { games }\end{array}$ & 10 & 0.84 & $\begin{array}{c}\text { All items are acceptable } \\
\text { and reliable }\end{array}$ \\
\hline \multirow{3}{*}{$\begin{array}{c}\text { Management of } \\
\text { Elementary } \\
\text { Education }\end{array}$} & Motivation & 5 & 0.82 & $\begin{array}{c}\text { All items are acceptable } \\
\text { and reliable }\end{array}$ \\
\hline & Communication & 7 & 0.86 & $\begin{array}{c}\text { All items are acceptable } \\
\text { and reliable }\end{array}$ \\
\hline & Organizing & 5 & 0.82 & $\begin{array}{c}\text { All items are acceptable } \\
\text { and reliable }\end{array}$ \\
\hline
\end{tabular}

Table 2 reveals the result of the reliability test for IMMEEQ for instructional media variables, these are projected media, non-projected visual and simulations and games. The Cronbach's alpha value for projected media is 0.86 covering up to 8 items, 0.80 for nonprojected visual with 6 items and 10 items from simulations and games with Cronbach's Alpha value of 0.84 . Based on management of elementary education indices, the Cronbach's alpha value for sub-indices are 0.82 for motivation, 0.86 for communication and 0.82 for organizing. Values above 0.70 are considered acceptable and reliable (Diamatopoulos, et.al, 2012; leady \& Ormrod, 2005; Brannen, 2017).

The participants were contacted in their respective offices to discuss the basis of the study before the distribution of the questionnaire. The researcher with the help of two research assistants personally administered the instruments to the head teachers and teachers of the sample public primary schools. Effective distribution of questionnaires was also aided with the cooperation of colleagues and friends in the sample schools. The questionnaires were administered to over 700 participants consisting of the selected head teachers and teachers in public primary schools. After 2 weeks, all the filled questionnaires were retrieved from the participants. However, a total of 693 questionnaires were returned and filled properly. Thus, the returned number meets the suggestion of Research Advisor (2006) with a number of 690 participants sample in this study. In the guideline provided by Zaki, Taqi, Sami and Nilofer (2012), this study emphasized the ethical issues in assuring anonymity and confidentiality of their responses.

\section{Data Analysis}

The data collected for the study were analyzed using descriptive statistics like mean and standard deviation to determine the objectives of the study. Inferential statistics such as ttest for the hypotheses. The t-critical value was compared to the significance level of $(0.5)$ to determine the acceptance or rejection of the hypotheses. 


\section{RESULTS AND DISCUSSION}

\section{Demographic Profile of Respondents}

This section presents a comprehensive result of the analysis made from the data collected in this study. It stated the demographic information of participants who participated using descriptive statistics.

Table 3. Demographic Profile of the Participants

\begin{tabular}{|c|c|c|c|}
\hline \multirow[t]{4}{*}{ Gender } & \multirow{4}{*}{$\begin{array}{c}\text { Female } \\
\text { Male }\end{array}$} & $N=690$ & Percentage $(\%)$ \\
\hline & & 403 & $59 \%$ \\
\hline & & 287 & $41 \%$ \\
\hline & & 690 & $100 \%$ \\
\hline \multirow[t]{5}{*}{ Age } & $21-30$ & 198 & $29 \%$ \\
\hline & $31-40$ & 208 & $30 \%$ \\
\hline & $41-50$ & 188 & $27 \%$ \\
\hline & 51 above & 96 & $14 \%$ \\
\hline & & 690 & $100 \%$ \\
\hline \multirow{4}{*}{ Qualification } & $\mathrm{NCE}$ & 359 & $52 \%$ \\
\hline & B.Ed. & 313 & $45 \%$ \\
\hline & Master degree & 18 & $3 \%$ \\
\hline & & 690 & $100 \%$ \\
\hline \multirow{4}{*}{$\begin{array}{c}\text { Year of } \\
\text { Experience }\end{array}$} & $1-10$ years & 277 & $40 \%$ \\
\hline & $10-20$ years & 304 & $44 \%$ \\
\hline & 21 years Above & 109 & $16 \%$ \\
\hline & & 690 & $100 \%$ \\
\hline
\end{tabular}

Table 3 shows the demographic information of the participants that participated in this study. From the table 403 participants (59\%) are female and 287 participants are male (41\%). In terms of average age of the participants, the majority 208 of the participants $(30 \%)$ are between ages 31-40 years while 96 participants $(14 \%)$ are between ages 51 years above. Based on the qualification of the participants, majority 359 participants $(52 \%)$ are NCE holder while 18 participants (3\%) are master degree holder. In the aspect of year of experience, majority 304 participants $(44 \%)$ have 10-20 years of experience, while 109 participants $(16 \%)$ have 21 years above experience in the sample public primary schools.

This part discusses the result of the findings. The findings were organized based on research objectives.

\section{Projected Media}

Objective 1: Determine the relationship between projected media and management of elementary education in Kwara State.

Table 4 presents the mean and standard deviation response of head teachers and teachers to the research questionnaire on projected media in public primary schools in Kwara State, Nigeria. 
Table 4. Mean and Standard Deviation of Variables on Projected Media

\begin{tabular}{|c|c|c|c|c|c|c|}
\hline \multirow[t]{2}{*}{$\mathbf{S} / \mathbf{N}$} & \multirow[t]{2}{*}{ Projected Media } & \multicolumn{2}{|c|}{$\begin{array}{l}\text { Head Teachers } \\
\text { Responses }\end{array}$} & \multicolumn{2}{|c|}{$\begin{array}{l}\text { Teachers } \\
\text { Responses }\end{array}$} & \multirow[t]{2}{*}{ Decision } \\
\hline & & & an SD & Meai & SD & \\
\hline 1 & $\begin{array}{l}\text { Projected media helps to bring the } \\
\text { world into the classroom. }\end{array}$ & 2.94 & 0.984 & 2.94 & 0.984 & Agreed \\
\hline 2 & $\begin{array}{l}\text { Improves good rapport between the } \\
\text { teacher and the learners. }\end{array}$ & 2.90 & 0.964 & 2.74 & 1.028 & Agreed \\
\hline 3 & $\begin{array}{l}\text { Enhances instant transmission of large } \\
\text { amount of information in the } \\
\text { classroom. }\end{array}$ & 2.95 & 0.967 & 2.87 & 0.992 & Agreed \\
\hline 4 & $\begin{array}{l}\text { Helps teachers to project the day's } \\
\text { learning objectives to the learners }\end{array}$ & 2.80 & 1.028 & 2.80 & 1.018 & Agreed \\
\hline 5 & $\begin{array}{l}\text { Assists teachers to present their lesson } \\
\text { logically and sequentially to the } \\
\text { learners. }\end{array}$ & 2.96 & 0.967 & 2.90 & 1.027 & Agreed \\
\hline 6 & $\begin{array}{l}\text { Helps teachers to deliver new content } \\
\text { appropriately and make it more } \\
\text { memorable. }\end{array}$ & 2.94 & 0.984 & 2.93 & 0.972 & Agreed \\
\hline 7 & Promotes learner's comprehension. & 2.98 & 0.931 & 2.87 & 1.027 & Agreed \\
\hline 8 & $\begin{array}{l}\text { Helps learners to recall what they have } \\
\text { learn in the previous class as well as } \\
\text { built upon it. }\end{array}$ & 2.92 & 0.955 & 2.84 & 1.003 & Agreed \\
\hline \multicolumn{2}{|c|}{ Overall Mean } & 2.92 & 0.973 & 2.86 & 1.006 & \\
\hline
\end{tabular}

(Mean $\geq 2.50$ Agree, Mean $<2.50$ Disagree)

The overall perception of the head teachers and teachers on projected media as shown in table 4 is interpreted as "Agreed" $(\mathrm{M}=2.92, \mathrm{SD}=0.973)$ and $(\mathrm{M}=2.86, \mathrm{SD}=1.006)$. This reveals that head teachers and teachers agreed that projected media improve effective management of elementary schools' education in Kwara State, Nigeria. Also, all the responses obtained mean values higher than the criterion mean value of 2.50 . This shows that the head teachers and teachers agreed that projected media i) helps to bring the world into the classroom $(\mathrm{M}=2.94, \mathrm{SD}=0.984)$ and $(\mathrm{M}=2.94, \mathrm{SD}=0.984)$, ii $)$ improves good rapport between the teacher and the learners $(M=2.90, S D=0.964)$ and $(M=2.74, S D=1.028)$, iii) Enhances instant transmission of large amount of information in the classroom $(\mathrm{M}=2.95, \mathrm{SD}$ $=0.967)$ and $(\mathrm{M}=2.87, \mathrm{SD}=0.992)$, iv) helps teachers to project the day's learning objectives to the learners $(\mathrm{M}=2.80, \mathrm{SD}=1.028)$ and $(\mathrm{M}=2.80, \mathrm{SD}=1.018), \mathrm{v})$ assists teachers to present their lesson logically and sequentially to the learners $(\mathrm{M}=2.83, \mathrm{SD}=$ 1.013) and $(\mathrm{M}=2.96, \mathrm{SD}=0.967)$ vi) helps teachers to deliver new content appropriately and make it more memorable $(\mathrm{M}=2.94, \mathrm{SD}=0.984)$ and $(\mathrm{M}=2.93, \mathrm{SD}=0,972)$ vii $)$ promotes learner's comprehension $(\mathrm{M}=2.98, \mathrm{SD}=0.931)$ and $(\mathrm{M}=2.87, \mathrm{SD}=1.027)$, viii $)$ helps learners to recall what they have learn in the previous class as well as built upon it $(\mathrm{M}=$ $2.92, \mathrm{SD}=0.955)$ and $(\mathrm{M}=2.84, \mathrm{SD}=1.003)$. 


\section{Non-projected visual}

Objective 2: Investigated the relationship between non-projected visual and management of elementary education in Kwara State.

Table 5 reveals the analysis of the sample responses for the construct of non-projected visual and management of elementary education in Kwara State.

Table 5. Non-Projected Visual as Responded by Head Teachers and Teachers

\begin{tabular}{|c|c|c|c|c|c|c|}
\hline \multirow[t]{2}{*}{$\mathbf{S} / \mathbf{N}$} & \multirow[t]{2}{*}{ Non-Projected Visual } & \multicolumn{2}{|c|}{$\begin{array}{l}\text { Head teachers } \\
\text { Responses }\end{array}$} & \multicolumn{2}{|c|}{$\begin{array}{l}\text { Teachers } \\
\text { Responses }\end{array}$} & \multirow[t]{2}{*}{ Decision } \\
\hline & & & in SD & Mean & SD & \\
\hline 9 & $\begin{array}{l}\text { Non-projected visual aids teachers' } \\
\text { explanations and make learning of } \\
\text { subject matter understandable to } \\
\text { learners during teaching and learning } \\
\text { process. }\end{array}$ & 2.87 & 1.001 & 2.84 & 1.006 & Agreed \\
\hline 10 & $\begin{array}{l}\text { Pictures shown on the display boards } \\
\text { or wall help learners gain more } \\
\text { attention. }\end{array}$ & 2.96 & 0.910 & 2.80 & 1.022 & Agreed \\
\hline 11 & $\begin{array}{l}\text { Helps in getting learners involve in } \\
\text { teaching by arousing their responses } \\
\text { to questions. }\end{array}$ & 2.88 & 0.996 & 2.93 & 0.964 & Agreed \\
\hline 12 & $\begin{array}{l}\text { Enhances retention and help learners } \\
\text { visualize a lesson. }\end{array}$ & 2.89 & 0.949 & 2.91 & 0.959 & Agreed \\
\hline 13 & $\begin{array}{l}\text { Enhances transfer of abstract concepts } \\
\text { into concrete objects. }\end{array}$ & 2.86 & 1.026 & 2.93 & 0.964 & Agreed \\
\hline 14 & $\begin{array}{l}\text { Helps to facilitate teaching and } \\
\text { learning }\end{array}$ & 2.97 & 0.977 & 2.78 & 1.032 & Agreed \\
\hline \multicolumn{2}{|c|}{ Overall Mean } & 2.91 & 0.972 & 2.87 & 0.912 & \\
\hline
\end{tabular}

(Mean > 2.50 Agree, Mean <2.50 Disagree)

Table 5 shown the overall perception of the head teachers and teachers on nonprojected visual is interpreted as "Agreed" $(\mathrm{M}=2.91, \mathrm{SD}=0.972)$ and $(\mathrm{M}=2.87, \mathrm{SD}=$ 0.912). This shows that the head teachers and teachers agreed that non-projected visual enhance effective management of elementary education in Kwara State, Nigeria. Furthermore, all the responses obtained mean values higher than the criterion mean value of 2.50. this shows that head teachers and teachers agree that non-projected visual i) aids teachers' explanations and make learning of subject matter understandable to learners during teaching and learning process. $(\mathrm{M}=2.87, \mathrm{SD}=1.001)$ and $(\mathrm{M}=2.84, \mathrm{SD}=1.006)$, ii $)$ pictures shown on the display boards or wall help learners gain more attention $(\mathrm{M}=2.96, \mathrm{SD}$ $=0.910)$ and $(\mathrm{M}=2.80, \mathrm{SD}=1.022)$, iii) helps in getting learners involve in teaching by arousing their responses to questions $(\mathrm{M}=2.88, \mathrm{SD}=0.996)$ and $(\mathrm{M}=2.93, \mathrm{SD}=0.964)$, iv $)$ enhances retention and help learners visualize a lesson $(\mathrm{M}=2.89, \mathrm{SD}=0.949)$ and $(\mathrm{M}=$ $2.91, \mathrm{SD}=0.959), \mathrm{v})$ enhances transfer of abstract concepts into concrete objects $(\mathrm{M}=2.86$, $\mathrm{SD}=1.026)$ and $(\mathrm{M}=2.93, \mathrm{SD}=0.964)$, vi $)$ helps to facilitate teaching and learning $(\mathrm{M}=$ $2.97, \mathrm{SD}=0.977)$ and $(\mathrm{M}=2.78, \mathrm{SD}=1.032)$. 


\section{Simulations and Games}

Objective 3: examine the relationship between simulations and games and management of elementary education in Kwara State.

Table 6 shown the analysis of the participants' responses for the construct of simulations and games and management of elementary education.

Table 6. Mean and Standard Deviation on Simulations and Games

\begin{tabular}{|c|c|c|c|c|c|c|}
\hline $\mathrm{S} / \mathrm{N}$ & Simulations and Games & \multicolumn{2}{|c|}{$\begin{array}{l}\text { Head Teachers } \\
\text { Responses }\end{array}$} & \multicolumn{2}{|c|}{$\begin{array}{l}\text { Teachers } \\
\text { Responses }\end{array}$} & Decision \\
\hline 15 & $\begin{array}{l}\text { Help to improve development of } \\
\text { continuity of ideas. }\end{array}$ & 2.87 & 0.949 & 2.88 & 0.940 & Agreed \\
\hline 16 & $\begin{array}{l}\text { Simulations and games enhance } \\
\text { effective learners' performance in } \\
\text { learning. }\end{array}$ & 2.95 & 0.976 & 3.02 & 0.926 & Agreed \\
\hline 17 & $\begin{array}{l}\text { Stimulate sense of imagination in } \\
\text { learners and change their } \\
\text { attitudes towards learning. }\end{array}$ & 2.88 & 0.994 & 2.87 & 1.022 & Agreed \\
\hline 18 & $\begin{array}{l}\text { Provide learners with necessary } \\
\text { facts and stimulate their thinking } \\
\text { and aesthetic values. }\end{array}$ & 2.91 & 0.958 & 2.92 & 0.961 & Agreed \\
\hline 19 & $\begin{array}{l}\text { Help learners to achieve } \\
\text { meaningful and productive } \\
\text { learning. }\end{array}$ & 3.02 & 0.888 & 2.98 & 0.922 & Agreed \\
\hline 20 & $\begin{array}{lrr}\text { Help learners } \quad \text { to } & \text { develop } \\
\text { cognitive, } & \text { affective } & \text { and } \\
\text { psychomotor } & \text { domain } & \text { of } \\
\text { education. } & & \end{array}$ & 2.80 & 1.021 & 2.85 & 1.018 & Agreed \\
\hline 21 & $\begin{array}{l}\text { Arouse enthusiasm and exciting } \\
\text { to all categories of learners in the } \\
\text { classroom. }\end{array}$ & 2.99 & 0.922 & 2.80 & 1.021 & Agreed \\
\hline 22 & $\begin{array}{l}\text { Promote teamwork among } \\
\text { learners. }\end{array}$ & 2.97 & 0.977 & 2.99 & 0.922 & Agreed \\
\hline 23 & $\begin{array}{l}\text { Help learners to develop sense of } \\
\text { fairness and self-control. }\end{array}$ & 2.78 & 1.034 & 2.87 & 0.981 & Agreed \\
\hline 24 & $\begin{array}{l}\text { Provide interactive session } \\
\text { between the teachers and the } \\
\text { learners }\end{array}$ & 2.87 & 0.946 & 2.90 & 0.970 & Agreed \\
\hline Over & all Mean & 2.90 & 0.985 & 2.91 & 0.968 & \\
\hline
\end{tabular}

(Mean > 2.50 Agree, Mean <2.50 Disagree)

Table 6 shown the overall perception of the head teachers and teachers on the simulations and games is interested as "Agreed" $(\mathrm{M}=2.90, \mathrm{SD}=0.985)$ and $(\mathrm{M}=2.91, \mathrm{SD}$ $=0.968)$. This reveals that the head teachers and teachers agreed that simulations and games bring about effective management of elementary education in Kwara State, Nigeria. In addition, all the responses obtained mean values higher than the criterion mean value of 2.50 . This shows that the head teachers and teachers agree that simulation and games i) help to improve development of continuity of ideas $(\mathrm{M}=2.87, \mathrm{SD}=0.949)$ and $(\mathrm{M}=2.88, \mathrm{SD}=$ 
$0.940)$, ii) enhance effective learners' performance in learning $(\mathrm{M}=2.95, \mathrm{SD}=0.976)$ and $(\mathrm{M}=3.02, \mathrm{SD}=0.926)$, iii) stimulate sense of imagination in learners and change their attitudes towards learning $(\mathrm{M}=2.88, \mathrm{SD}=0.994)$ and $(\mathrm{M}=2.87, \mathrm{SD}=1.002)$, iv) provide learners with necessary facts and stimulate their thinking and aesthetic values $(\mathrm{M}=2.91, \mathrm{SD}$ $=0.958)$ and $(\mathrm{M}=2.92, \mathrm{SD}=0.961), \mathrm{v})$ help learners to achieve meaningful and productive learning $(\mathrm{M}=3.02, \mathrm{SD}=0.888)$ and $(\mathrm{M}=2.98, \mathrm{SD}=0.922)$, vi) help learners to develop cognitive, affective and psychomotor domain of education $(\mathrm{M}=2.80, \mathrm{SD}=1.021)$ and $(\mathrm{M}=$ $2.85, \mathrm{SD}=1.018)$, vii) Arouse enthusiasm and exciting to all categories of learners in the classroom $(\mathrm{M}=2.99, \mathrm{SD}=0.922)$ and $(\mathrm{M}=2.80, \mathrm{SD}=1.021)$, viii) promote teamwork among learners $(\mathrm{M}=2.97, \mathrm{SD}=0.977)$ and $(\mathrm{M}=2.99, \mathrm{SD}=0,922)$, ix $)$ help learners to develop sense of fairness and self-control $(\mathrm{M}=2.87, \mathrm{SD}=0.946)$ and $(\mathrm{M}=2.90, \mathrm{SD}=$ $0.970), \mathrm{x})$ provide interactive session between the teachers and the learners $(\mathrm{M}=2.87, \mathrm{SD}=$ $0.946)$ and $(\mathrm{M}=2.90, \mathrm{SD}=0.970)$.

\section{Hypotheses Testing}

T-test statistical analysis was used in this study to test the set hypotheses as follow:

$\mathrm{H}_{01}$ : There is no significant difference between the mean scores of head teachers and teacher on projected media and management of elementary education.

Table 7. Projected Media and Management of Elementary Education

\begin{tabular}{llrlllll}
\hline Variable & $\mathbf{N}$ & $\overline{\boldsymbol{x}}$ & SD & $\mathbf{d f}$ & t-cal & t-crit & Decision \\
\hline Head teachers & 306 & 2.92 & 0,973 & & & & \\
Teachers & 384 & 2,86 & 1.006 & & & & Accepted \\
\hline
\end{tabular}

Table 7 indicates the t-test analysis between the mean scores of head teachers and teachers' responses on projected media and management of elementary education. the tcalculated value of 0.86 is less than $t$-critical value of 1.96. this means there is no significant difference between the responses of head teachers and teachers on projected media and management of elementary education. Therefore, the hypothesis which states that there is no significant difference between projected media and management of elementary education is accepted.

$\mathrm{H}_{02}$ : There is no significant difference between the mean scores of head teachers and teachers on non-projected visual and management of elementary education.

Table 8. Non-projected Visual and Management of Elementary Education

\begin{tabular}{llrlllll}
\hline Variable & $\mathbf{N}$ & $\overline{\boldsymbol{x}}$ & SD & df & t-cal & t-crit & Decision \\
\hline Head teachers & 306 & 2.91 & 0.972 & & & & \\
Teachers & 384 & 2.87 & 0.912 & & & & Accepted \\
\hline
\end{tabular}

Table 8 indicates that the t-test analysis between the mean scores of head teachers and teachers' responses on non-projected visual and management of elementary education. The tcalculated value of 0.88 is less than t-critical value 1.96. This implies that there is no significant difference between the responses of head teachers and teachers on non-projected visual and management of elementary education. Therefore, the hypothesis which states that there is no significant difference between non-projected visual and management of elementary education is accepted. 
$\mathrm{H}_{03}$ : There is no significant difference between the mean scores of head teachers and teachers on simulations and games and management of elementary education.

Table 9. Simulations and Games and Management of Elementary Education

\begin{tabular}{llrlllll}
\hline Variable & $\mathbf{N}$ & $\overline{\boldsymbol{x}}$ & SD & df & t-cal & t-crit & Decision \\
\hline Head teachers & 306 & 2.90 & 0.985 & & & & \\
Teachers & 384 & 2.91 & 0.968 & & & & Accepted \\
\hline
\end{tabular}

Table 9 shows the t-test analysis between the mean scores of head teachers and teachers' responses on simulations and games and management of elementary education. The t-calculated value of 0.77 is less than t-critical value 1.96. This depicts that there is no significant difference between the responses of head teachers and teachers on simulations and games and management of elementary education. Therefore, the hypothesis which states that there is no significant difference between simulations and games and management of elementary education is accepted.

The finding in table 4 reveals that projected media improve effective management of elementary education in Kwara State, Nigeria, such that it helps to bring the world into the classroom, improves good rapport between the teacher and the learners, enhances instant transmission of large amount of information in the classroom, helps teachers to project the day's learning objectives to the learners, assists teachers to present their lesson logically and sequentially to the learners, helps teachers to deliver new content appropriately and make it more memorable, promotes learners' comprehension as well as helps learners to recall what they have learn in the previous class as well as built upon it. Results from hypothesis one shown that there is no significant difference between projected media and management of elementary education in Kwara State, Nigeria. This finding agreed with Dhakal (2017) that projected media improved the overall quality of teaching and learning. This finding conforms to Hilda and Bernard (2015) that instructional media enhance better learners understanding of the concepts being taught. This finding is in line with Stephen and Isaac (2013) that learners taught with instructional media perform positively better than those taught without instructional media.

The findings in table 5 reveals that non-projected visual enhance effective management of elementary education in Kwara State, Nigeria, such that it aids teachers' explanations and make learning of subject matter understandable to learners during teaching and learning process, help learners gain more attention through pictures shows on the boards or wall, helps in getting learners involve in teaching by arousing their responses to questions, enhances retention and help learners visualize a lesson, enhances transfer of abstract concepts into concrete objects as well as helps to facilitate teaching and learning. Results of hypothesis two analysis revealed that there is no significant difference between non-projected visual and management of elementary education. This finding is germane to Danmole and Lameed (2017) that non-projected visual bring learners face to face with world so as to achieve educational goals. This finding agreed with Onasanya and Omosewo (2011) that use of nonprojected visual improved students understanding and led to high academic achievement. This finding also in line with Ogada, Akume, Edo and Ogi (2019) that instructional media bridge the gap between theoretical and practical knowledge as well as facilitate effective teaching and learning.

The findings in table 6 show that simulations and games bring about effective management of elementary education in Kwara State, Nigeria such that it to improve 
Indonesian Journal of Elementary Teachers Education (IJETE)

p-ISSN: 2615-2606 \& e-ISSN: 2615-7853

Volume 1, Number 1, May 2020

https://journal.uniku.ac.id/index.php/ijete

development of continuity of ideas, enhance effective learners' performance in learning, stimulate sense of imagination in learners and change their attitudes towards learning, provide learners with necessary facts and stimulate their thinking and aesthetic values, help learners to achieve meaningful and productive learning, help learners to develop cognitive, affective and psychomotor domain of education, arouse enthusiasm and exciting to all categories of learners in the classroom, promote teamwork among learners, help learners to develop sense of fairness and self-control, help learners to develop sense of fairness and selfcontrol as well as provide interactive session between the teachers and the learners. Result from hypothesis three analysis revealed that there is no significant difference between simulations and games and management of elementary education. This finding agreed with Merchant (2014) that simulations and games enhanced learners psychomotor, affective and cognitive skills. This finding is in consonance with Thompson and Dass (2000) that learners who engaged in simulations and games showed a significant increase in self-efficacy and better communication skills. This finding conforms to Shin, Park and Kim (2015) that simulation and games provide learners with authentic clinical situation and allowing them to perform in realistic and safe environment. This finding agreed with Gegenfurtner, QuesadaPallares and Knogler (2014) that simulation and games enhance self-efficacy and transfer of learning as well as effectivemotivational outcomes. This finding agreed with Abdullahi and Tijani (2019) that game-based learning helps learners to collaborate and enhance better selfmanagement. This finding on the contrary disagreed with Carenys and Moya (2016) that simulation and games decrease peer interaction and communication which serve as a hindrance for learning.

\section{CONCLUSION AND RECOMMENDATION}

Instructional media in an importance resources in enhancing effective management of elementary education towards the realization of educational goals and objectives. Based on the findings of this study, the researcher concluded that there were no significant differences between the three indices of instructional media (projected media, non-projected visual \& simulation and games) and management of elementary schools' education as they were found to connect on another. The findings of this study will be of benefits to government, teachers, head teachers and stakeholders in education. The findings of this study will help the government and stakeholders to understand the importance of using instructional media to impart knowledge in learners so as to ensure effective management of elementary education. Also, this study will help teachers to continue make use of appropriate and relevant instructional material to arouse the interest of the learners. Furthermore, this finding would serve as a reference point for further researchers in the field of education.

Government and head teachers should make adequate provision of projected media for teachers to disseminate information to learners in the classroom so as to helps bring the world into the classroom, improves good rapport between the teacher and the learners, enhances instant transmission of large amount of information in the classroom, helps teachers to project the day's learning objectives to the learners, assists teachers to present their lesson logically and sequentially to the learners, helps teachers to deliver new content appropriately and make it more memorable, promotes learners' comprehension as well as helps learners to recall what they have learn in the previous class as well as built upon it. Head teachers should continue to encourage teachers to make use of non-projected visual to arouse the interest and call the attention of learners in order to aids teachers' explanations and make learning of subject matter understandable to learners during teaching and learning process, helps learners gain more attention through pictures shows on the boards or wall, helps in getting learners 
involve in teaching by arousing their responses to questions, enhances retention and help learners visualize a lesson, enhances transfer of abstract concepts into concrete objects as well as helps to facilitate teaching and learning. Teachers should also make use of simulation and games to enhance effective learners' performance in learning. improve development of continuity of ideas, stimulate sense of imagination in learners and change their attitudes towards learning, provide learners with necessary facts and stimulate their thinking and aesthetic values, help learners to achieve meaningful and productive learning, help learners to develop cognitive, affective and psychomotor domain of education, arouse enthusiasm and exciting to all categories of learners in the classroom, promote teamwork among learners, help learners to develop sense of fairness and self-control, help learners to develop sense of fairness and self-control as well as provide interactive session between the teachers and the learners. 


\section{REFERENCES}

Abdullahi, N.J.K. \& Tijani, A. A. (2019). Digitization in education system and management of early childhood care education in Nigeria. Southeast Asia Early Childhood Journal, 8 (2), 28-42.

Abdullahi, N.J.K., Musa, R.M. \& Mayachi, M.L. (2016). Managing education for sustainable peace and national development: focus on principals' managerial roles in Kwara State, Nigeria. International Journal of Tropical Education Issue. 1 (1), 35-43.

Adobor, H., Damesshfar, A. (2006). Management simulations: determining their effectiveness. Journal of Management Development, 25, 151-168.

Allen, I. E. \& Christopher, A. S. (2007). Likert scales and data analyses. Quality Progress, 40 (7),64-65.

Awolaju, B. A. (2016). Instructional media as correlates of students' academic performance in biology in senior secondary schools in Osun State. International Journal of Information and Education Technology, 6 (9), 705-708.

Bergkvist, L. \& John, R. R. (2007). The predictive validity of multi-item versus single-item measures of the same constructs. Journal of Marketing Research, 44 (2), 175-184.

Brannen, J. (2017). Mixing methods: qualitative and quantitative research. Retrieved from https://www.taylorfrancis.com/books/9781351917186.

Bright, C. M. \& Abdulganiyu, S. (2015). Evaluation of modern development in teaching and learning process through instructional materials utilization. International Journal of Multidisciplinary Research and Development, 2 (9), 123-127.

Carenys, J., \& Moya, S. (2016). Digital game-based learning in accounting and business education. Journal of Accounting Education, 25 (6), 598-651.

Danmole, B. T., \& Lameed, S. N. (2017). Exploring annotated drawing for improving Nigeria secondary school students' achievement in genetics. International Journal of Biology Education, 3 (1), 202-220.

Dhalka, K. R. (2017). Availability and utilization of instructional materials in teaching geography in secondary schools. Journal of Geography, 17, 51-58.

Diamantopoulos, A., Marko. S., Chrisoph, F., Petra, W. \& Sebastian, K. (2012). Guideline for choosing between multi-item and single-item scales for construct measurement: a predictive validity perspective. Journal of the Academy of Marketing Science, 40 (3), 434-449.

Dolnicar, S., \& Grun, B. (2007). User-friendliness of answer format: an empirical comparison. Australasian Journal of Market and Social Research, 15 (1), 19-28. 
Drew, C. J., Hardman, M. \& Hosp, J. (2008). Designing and conducting research in education. Los Angeles, CA: Sage.

Federal Republic of Nigeria. (2013). National policy on education: Federal Ministry of Education. Yaba, Lagos - Nigeria.

Fleming, N. D. (2006). V.A.R.K.: visual, auditory, read/write, kinesthetic. New Zealand: Bonwell Green Mountain Falls.

Gegenfurtner, A., Quesada-Pallares, C., \& Knogler, M. (2014). Digital simulation-based training: a meta-analysis. British Journal of Educational Technology, 45 (6), 10971114.

Hilda, N. T. \& Bernard, C. (2015). Availability and use of instructional materials in the teaching of conflict and conflict resolution in primary schools in Nandi North District, Kenya. International Journal of Education and Practice, 3 (6), 224-234.

Igbokwe, U. O., \& Igbokwe, C. C. (2010). The Nigeria education system. In I. L. Anukam, P. O. Okunamiri \& R. N. O. Ogbonna (Eds.). Basic text on educational management. Eettech Versatile, Imo State.

Johnson, B., \& Christensen, L. (2008). Education of research: qualitative, quantitative, and mixed approaches $\left(3^{\text {rd }}\right.$ ed.). Thousand Oaks, CA: Sage.

Leady, P. D., \& Ormrod, J. E. (2005). Practical research: planning and design. New Jersey: Pearson Merril Prentice Hall.

Lewis, M. A. \& Maylor, H. R. (2007). Game playing and operations management education. International Journal of Production Economics, 105, 134-149.

Merchant, Z., Goetz, E. T., Cifuentes, L., Keaney-Kennicutt, W., \& Davis, T. J. (2014). Effectiveness of virtual reality-based instruction on students' learning outcome in K12 and higher education: a meta-analysis. Journal of Computers and Education, 70, 29-40.

Obwoge, R. O., \& Mosol, J. P. (2016). Understanding the utilization of instructional media in training health professional. IOSR Journal of Nursing and Health Science, 5 (3), 1-8.

Ogada, A. A., Akume, R. V., Edo, M. O., \& Ogi, J. U. (2019). An overview of the relevance of instructional materials in early childhood care education. International Journal of Science and Research Methodology, 12 (1), 129-142.

Okpechi, P. A. \& Denwigwe, C. P. (2017). The teacher and teaching with instructional materials in the teaching of science subjects and the contribution of guidance and counsellors therein. British Journal of Education, 5 (13), 10-18. 
Olubola, S. \& Francisca, A. (2013). Effect of simulation games and computer assisted instruction on performance in primary science in Lagos State, Nigeria. West East Journal of Social Sciences, 2 (2), 117-122.

Onasanya, S. A. (2016). Concepts, functions and typed of instructional resources. In A. A. Adegoke, R. A. Lawal, A. G. A. S. Oladosu \& A. A. Jekayinfa (eds.). Introduction to teaching methodology. Haytee Press and Publishing Company Nigeria Ltd, Ilorin Kwara State, Nigeria.

Onasanya, S. A. \& Omosewo, E. O. (2011). Effect of improvised and standard instructional materials on secondary school students' academic performance in physics in Ilorin, Nigeria. Singapore Journal of Scientific Research, 1, 68-78.

Oladosun, A. G. A. S. (2016). Teaching as a component of instruction. In A. A. Adegoke, R. A. Lawal, A. G. A. S. Oladosu \& A. A. Jekayinfa (eds.). Introduction to teaching methodology. Haytee Press and Publishing Company Nigeria Ltd, Ilorin Kwara State, Nigeria

Pasin, F., \& Groux, H. (2011). The impact of a simulation game on operations management education. Computers and education, 57, 1240-1254.

Research Advisor (2006). Sample size table. Retrieved from http://WWW.reseachadvisor.com.

Shin, S., Park, J. H., \& Kim, J. H. (2015). Effectiveness of patient simulation in nursing education: meta-analysis. Nurse Education Today, 35 (1), 176-182.

Stephen, A. A., \& Isaac, T. I. (2013). The influence of instructional materials on academic performance of senior secondary school students in chemistry in Cross River State. Global Journal of Educational Research, 12, 39-45.

Thompson, G. H. \& Dass, P. (2000). Improving students' self-efficacy in strategic management: the relative impact of cases and simulations, Journal of Simulation and Gaming, 3 (1), 22-41.

Yusuf, M. O., \& Ogunlade, O. O. (2016). Principle of selection, utilization, adaptation and improvisation of instructional resources. In A. A. Adegoke, R. A. Lawal, A. G. A. S. Oladosu \& A. A. Jekayinfa (eds.). Introduction to teaching methodology. Haytee Press and Publishing Company Nigeria Ltd, Ilorin Kwara State, Nigeria.

Zaki, S., Taqi, S., Sami, L., \& Nilofer, A. (2012). Ethical guidelines on authorship. India Journal of Dental Research, 23 (2), 291-292. 
Abdullahi Nimota Jibola Kadir

INSTRUCTIONAL MEDIA AND MANAGEMENT OF ELEMENTARY SCHOOLS

EDUCATION IN KWARA STATE NIGERIA 